\title{
Molecular characterization of alkyl nitrates in atmospheric aerosols by ion mobility mass spectrometry
}

\author{
Xuan Zhang ${ }^{1}$, Haofei Zhang ${ }^{2,3}$, Wen $\mathrm{Xu}^{4}$, Xiaokang Wu ${ }^{5}$, Geoffrey S. Tyndall ${ }^{1}$, John J. Orlando ${ }^{1}$, John T. Jayne ${ }^{4}$, \\ Douglas R. Worsnop ${ }^{4}$, and Manjula R. Canagaratna ${ }^{4}$ \\ ${ }^{1}$ Atmospheric Chemistry Observation \& Modeling Laboratory, National Center for Atmospheric \\ Research, Boulder, CO 80301, USA \\ ${ }^{2}$ Department of Chemistry, University of California, Riverside, CA 92521, USA \\ ${ }^{3}$ Environmental Toxicology Program, University of California, Riverside, CA 92521, USA \\ ${ }^{4}$ Center for Aerosol and Cloud Chemistry, Aerodyne Research, Inc., Billerica, MA 01821, USA \\ ${ }^{5}$ Department of Atmospheric Sciences, Texas A\&M University, College Station, TX 77843, USA
}

Correspondence: Xuan Zhang (xuanz@ucar.edu) and Manjula R. Canagaratna (mrcana@aerodyne.com)

Received: 7 May 2019 - Discussion started: 19 June 2019

Revised: 7 September 2019 - Accepted: 9 September 2019 - Published: 21 October 2019

\begin{abstract}
We demonstrate the capability of the ion mobility mass spectrometry (IMS-MS) for molecular characterization of reactive and short-lived alkyl nitrates (ANs) in atmospheric aerosols. We show significantly enhanced sensitivity towards the intact molecules of ANs by ultimately 2 orders of magnitude with the addition of inorganic anions such as chloride and nitrate to the negative electrospray to promote the ion adduct formation. This approach enables the measurement of ANs that have a low tendency to form molecular ions on their own with an improved limit of detection in the range of 0.1 to $4.3 \mu \mathrm{M}$. Molecular identities of the ANs are well constrained by the developed correlation between the collision cross section and mass-to-charge ratio, which provides a two-dimensional separation of the $-\mathrm{ONO}_{2}$-containing compounds on the basis of their molecular size and geometry. Structural information of the nitrate molecules is further probed by the identification of characteristic fragments produced from the collision-induced dissociation of parent AN adducts. Application of the IMS-MS technique is exemplified by the identification of hydroxy nitrates in secondary organic aerosols produced from the photochemical oxidation of isoprene.
\end{abstract}

\section{Introduction}

Alkyl nitrates (ANs; ANs are $\mathrm{RONO}_{2}$ ) constitute a major fraction and serve as a temporary reservoir of total reactive nitrogen oxides in the atmosphere (Perring et al., 2013). ANs are primarily produced from the $\mathrm{OH}$-initiated oxidation of volatile organic compounds (VOCs) in the presence of nitrogen oxides $\left(\mathrm{NO}_{x}\right)$ during daytime and the $\mathrm{NO}_{3}$-initiated oxidation of alkenes during nighttime. Once formed, ANs are primarily subjected to further chemical transformation, leading to the recycling of $\mathrm{NO}_{x}$, partitioning into the particlephase-forming secondary organic aerosols (SOAs) or deposition resulting in the loss of atmospheric $\mathrm{NO}_{x}$. Characterization of alkyl nitrates is of crucial importance in understanding the regional $\mathrm{NO}_{x}$ budget, tropospheric ozone production and chemical mechanisms leading to the SOA formation (Brown et al., 2009; Farmer et al., 2011; Rollins et al., 2012; Rosen et al., 2004).

A suite of analytical techniques, such as thermaldissociation laser-induced-fluorescence spectroscopy (TDLIF; Thornton et al., 2000; Day et al., 2002; Wooldridge et al., 2010), chemical ionization mass spectrometry (CIMS; Beaver et al., 2012; Loza et al., 2014; Krechmer et al., 2015; Nguyen et al., 2015; Schwantes et al., 2015, 2017b; Teng et al., 2015; Xiong et al., 2015; Lambe et al., 2017) and gas chromatography coupled with electron capture detection (GC-ECD; Atlas, 1988; O’Brien et al., 1995; He et al., 2011), have been employed for in situ measurement of total and 
individual ANs in the gas phase. Observations of ANs in the particle phase, however, are rather limited due to the intensive denitrification during the preparation and analysis of particle samples. Efforts have been made to characterize the total amount of ANs and the number of $-\mathrm{ONO}_{2}$ functional groups using TD-LIF and Fourier-transform infrared spectroscopy (FTIR; Rollins et al., 2010; Russell et al., 2011). The $\mathrm{NO}_{2}^{+} / \mathrm{NO}^{+}$ratio derived from the aerosol mass spectrometry (AMS) measurements has also been used as an indicator for the presence of alkyl nitrates in submicrometer particles (Farmer et al., 2010; Kiendler-Scharr et al., 2016; $\mathrm{Xu}$ et al., 2017, 2018). These techniques have provided important insights into the prevalence and abundance of ANs in atmospheric aerosols, although the molecular information of individual ANs is lacking. Recent development on the filter inlet for gases and aerosols (FIGAERO) interfaced with the CIMS instrument has allowed for online speciation and quantification of functionalized alkyl nitrates in the particle phase (Lee et al., 2016). While the molecular composition of any given compounds can be inferred from the mass spectra, structural information on isomeric and isobaric species that are commonly produced from atmospheric chemical transformation is not available from CIMS measurements.

In this study, we present the first demonstration of the ion mobility mass spectrometry (IMS-MS) interfaced with an electrospray ionization (ESI) source that enables the molecular characterization of alkyl nitrates in atmospheric aerosols. The IMS technique has been widely employed in the fields of biochemistry and homeland security. The majority of previous studies that adapted ESI for IMS analysis employed either the desorption electrospray ionization (DESI) to detect trace amounts of ANs on ambient surfaces (Cotte-Rodríguez et al., 2005; Popov et al., 2005; Takáts et al., 2005; Justes et al., 2007) or the secondary electrospray ionization (SESI) for gas-phase AN measurements (Tam and Hill, 2004; MartínezLozano et al., 2009; Crawford and Hill, 2013). The analysis of ANs directly from liquid solutions, on the other hand, has not yet been widely explored. Hilton et al. (2010) found that the $\mathrm{NO}_{3}^{-}$fragment dominates the IMS spectra of several types of ANs measured in the negative ESI, suggesting that these nitrate molecules readily fragment due to the thermally labile nature of the $-\mathrm{ONO}_{2}$ functionality, thereby resulting in the loss of molecular information of the targeted compounds. Here we show that with the addition of selected anions, including chloride, nitrate, iodide and acetate, into the sprayed solution, molecular structures of ANs are largely maintained by producing ion clusters of the form $[\mathrm{M}+\mathrm{Cl}]^{-},\left[\mathrm{M}+\mathrm{NO}_{3}\right]^{-}$, $[\mathrm{M}+\mathrm{I}]^{-}$and $[\mathrm{M}+\mathrm{Ac}]^{-}$, respectively. The anion attachment represents a new option for the detection of the $-\mathrm{ONO}_{2}$ functionality that is unlikely to produce a measurable amount of molecular ions on its own during ESI. The optimal anion concentration to essentially promote the ion adduct formation is on the order of millimoles, which is significantly higher than the level of concentrations naturally present in ambient aerosols. We develop an intrinsic correlation between the collision cross section and mass-to-charge ratio based on the ion mobility measurements of five AN standards, providing a two-dimensional identification of unknown molecules that are likely containing the $-\mathrm{ONO}_{2}$ moiety. Additionally, the molecular identity of ANs can be verified via the characteristic fragment produced from the collision-induced dissociation of the parent ion adducts. We apply the IMS-MS technique to identify ANs in SOA produced from isoprene photochemistry.

\section{Experiments}

\subsection{Materials}

Organic nitrate and nitro standards stored in acetonitrile ampules, including 1-mononitroglycerin $\left(100 \mu \mathrm{gL}^{-1}\right.$, Sigma-Aldrich), 1,3-dinitroglycerin $\left(100 \mu \mathrm{gL}^{-1}\right.$, SigmaAldrich), pentaerythritol tetranitrate $\left(1000 \mu \mathrm{g} \mathrm{mL}^{-1}\right.$, Sigma-Aldrich), hexahydro-1,3,5-trinitro-1,3,5-triazine $\left(1000 \mu \mathrm{g} \mathrm{mL}^{-1}\right.$, Sigma-Aldrich) and 2,4-dinitrotoluene $\left(1000 \mu \mathrm{g} \mathrm{mL}^{-1}\right.$, Sigma-Aldrich), were further diluted with methanol (HPLC grade; J. T. Baker) to $5 \mu \mathrm{M}$ or less for characterizing the performance of the ion mobility mass spectrometer. Stock solutions of ammonium acetate (>99\%, Sigma-Aldrich), ammonium chloride (>99\%, Sigma-Aldrich), sodium nitrate (>99\%, Sigma-Aldrich) and sodium iodide (>99\%, Sigma-Aldrich) were prepared at a concentration of $10 \mathrm{mM}$ in methanol. They were used as additives at typical concentrations of $0.01-0.1 \mathrm{mM}$ in the AN methanol solutions to promote the ion adduct formation.

\subsection{Experiments}

SOA samples containing alkyl nitrates were generated from the $\mathrm{OH}$ oxidation of isoprene under high- $\mathrm{NO}_{x}$ conditions in the NCAR $10 \mathrm{~m}^{3}$ Atmospheric Simulation Chamber (Zhang et al., 2018). $\mathrm{H}_{2} \mathrm{O}_{2}$ was used as the $\mathrm{OH}$ source by evaporating a $133 \mu \mathrm{L}$ aqueous solution ( $30 \mathrm{wt} \%$ in water; Sigma-Aldrich) into the chamber with $5 \mathrm{~L} \mathrm{~min}^{-1}$ purified air for $\sim 120 \mathrm{~min}$, resulting in a starting concentration of $\sim 4 \mathrm{ppm}$ (Wang et al., 2009; He et al., 2010; Zhao et al., 2011; Cappa et al., 2013; Zhang and Seinfeld, 2013; Schwantes et al., 2017a). Isoprene was injected into the chamber by evaporating a $\sim 17 \mu \mathrm{L}$ liquid standard ( $\geq 99 \%$, Sigma-Aldrich) with $5 \mathrm{~L} \mathrm{~min}^{-1} \mathrm{pu}$ rified air for $\sim 20 \mathrm{~min}$, resulting an initial concentration of $\sim 500 \mathrm{ppb}$. NO was injected into the chamber from a concentrated $\mathrm{NO}$ cylinder source $\left(\mathrm{NO}=133.16 \mathrm{ppm}\right.$, balance $\left.\mathrm{N}_{2}\right)$ to achieve an initial concentration of $\sim 500 \mathrm{ppb}$. Seed aerosol was injected into the chamber by atomizing $0.06 \mathrm{M}$ aqueous ammonium-sulfate solution to provide a sufficient surface area for the partitioning of alkyl nitrates (Nguyen et al., 2014a, b; Zhang et al., 2014a, 2015b; McVay et al., 2016; Nah et al., 2016; Huang et al., 2018). The chamber contents were allowed to mix for $\sim 30 \mathrm{~min}$ before the onset of irradiation. After $\sim 2 \mathrm{~h}$ photooxidation, NO was nearly depleted 
( $>5 \mathrm{ppb}$ ) and the irradiation was ceased. The SOA produced was then collected on Teflon filters ( $47 \mathrm{~mm}$ diameter, $0.5 \mu \mathrm{M}$ pore size; Millipore) through active sampling at a flow rate of $10 \mathrm{~L} \mathrm{~min}^{-1}$ for $\sim 3 \mathrm{~h}$ (Schilling Fahnestock et al., 2014; Zhang et al., 2014b; Huang et al., 2016; Thomas et al., 2016). Filters were stored in a $-20^{\circ} \mathrm{C}$ freezer prior to analysis (Riva et al., 2016). SOA samples were extracted in $20 \mathrm{~mL}$ HPLCgrade methanol by $45 \mathrm{~min}$ of sonication at $\sim 273 \mathrm{~K}$ and then concentrated to $\sim 5 \mathrm{~mL}$ with the assistance of a $\sim 2 \mathrm{~L} \mathrm{~min}^{-1}$ $\mathrm{N}_{2}$ stream.

\subsection{Instrumental}

The electrospray ionization drift-tube ion mobility spectrometer (DT-IMS) interfaced to a time-of-flight mass spectrometer (TOFMS) was utilized in the characterization of ANs. The instrument was designed and manufactured by Tofwerk (AG, Switzerland), with detailed descriptions and schematics provided by previous studies (Kaplan et al., 2010; Groessl et al., 2015; Krechmer et al., 2016; Zhang et al., 2016b, 2017). Here we will present the instrument operation protocols specific to the AN measurement.

AN standards and SOA filter extracts were delivered to the ESI source via a $250 \mu \mathrm{L}$ gas-tight syringe (Hamilton) held on a syringe pump (Harvard Apparatus) at a flow rate of $1 \mu \mathrm{L} \mathrm{min}{ }^{-1}$. The optimal ESI potential to readily generate stable ion adducts while minimizing the corona discharge was found to be $-1800 \mathrm{~V}$. The negatively charged mist generated at the emitter tip is introduced into the drift tube through a Bradbury-Nielson (BN) ion gate located at the entrance with the assistance of $1 \mathrm{~L} \mathrm{~min}^{-1}$ nitrogen sheath gas. The $\mathrm{BN}$ ion gate was operated at the Hadamard transform mode, with a closure voltage of $50 \mathrm{~V}$ and a gate pulse frequency of $1.2 \times 10^{3} \mathrm{~Hz}$. The drift tube was held at a constant temperature $(340 \pm 3 \mathrm{~K})$ and atmospheric pressure ( $\sim 766$ Torr $)$. A counter flow of $\mathrm{N}_{2}$ drift gas was introduced at the end of the drift region at a flow rate of $1.2 \mathrm{~mL} \mathrm{~min}^{-1}$. Ion mobility separation was carried out at a field strength ranging from 300 to $400 \mathrm{~V} \mathrm{~cm}^{-1}$. After exiting from the drift tube, ions were focused into a pressure-vacuum interface that includes two segmented quadrupoles $\left(\mathrm{Q}_{1}\right.$ and $\left.\mathrm{Q}_{2}\right)$ through an ion lens and a nozzle. Note that the potential gradient applied to the ion lens and nozzle should be limited to $500 \mathrm{~V}$ or less to prevent intensive fragmentation of the molecular ions. The frequency and amplitude were set as $1.5 \times 10^{6} \mathrm{~Hz}$ and $196 \mathrm{~V}$ for $\mathrm{Q}_{1}$ and $1.5 \times 10^{6} \mathrm{~Hz}$ and $250 \mathrm{~V}$ for $\mathrm{Q}_{2}$. Collision-induced dissociation (CID) can be performed by adjusting the voltages on the ion optical elements between the two quadruple stages. Over the course of a CID program, the quadrupoles were set to $1.3 \times 10^{6} \mathrm{~Hz}$ and $120 \mathrm{~V}$ for $\mathrm{Q}_{1}$ and $1.2 \times 10^{6} \mathrm{~Hz}$ and $150 \mathrm{~V}$ for $\mathrm{Q}_{2}$ to ensure good transmission of low masses $(m / z<100)$.

The ESI IMS TOFMS instrument was operated in the $\mathrm{m} / \mathrm{z}$ range of 20 to 1500 , with a total recording time of $60 \mathrm{~s}$ for each dataset. The mass spectrometer was calibrated using sodium nitrate, ammonium phosphate, sodium dodecyl sul-
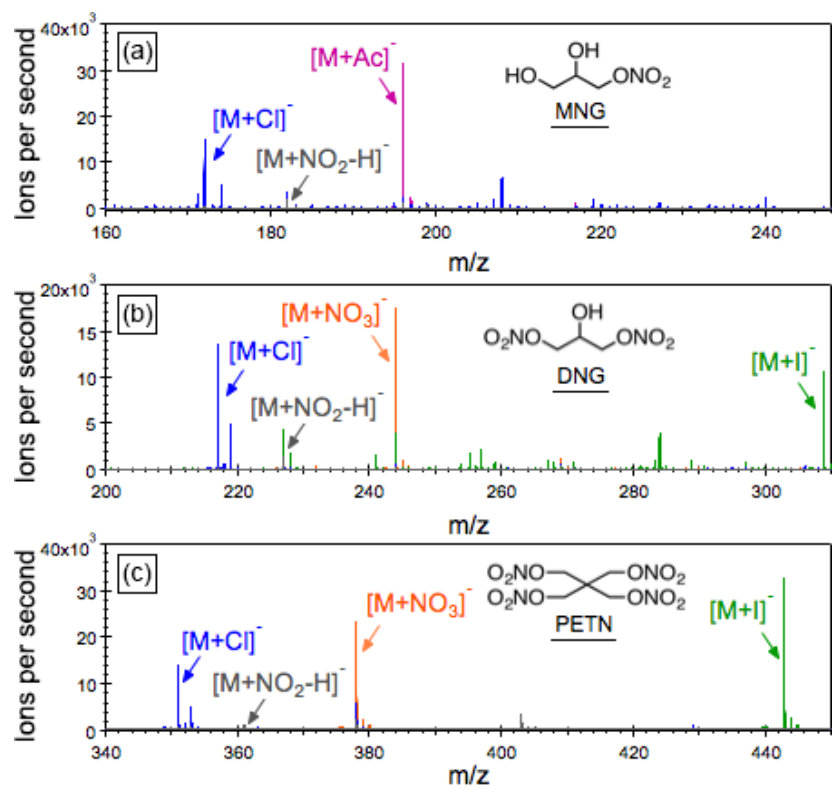

Figure 1. Negative ESI mass spectra of $5 \mu \mathrm{M}$ 1-mononitroglycerin (MNG), 1,3-dinitroglycerin (DNG) and pentaerythritol tetranitrate (PETN) dissolved in pure methanol (gray), methanol with $0.1 \mathrm{mM}$ ammonium acetate $\left(\mathrm{NH}_{4} \mathrm{Ac}\right.$; purple), methanol with $0.1 \mathrm{mM}$ ammonium chloride $\left(\mathrm{NH}_{4} \mathrm{Cl}\right.$; blue), methanol with $0.1 \mathrm{mM}$ sodium nitrate $\left(\mathrm{NaNO}_{3}\right.$; orange) and methanol with $0.1 \mathrm{mM}$ sodium iodide (NaI; green). These three alkyl nitrates, which do not readily produce a significant amount of molecular ions on their own during negative ESI, are observed as clusters with acetate $\left(\mathrm{Ac}^{-}\right)$, chloride $\left(\mathrm{Cl}^{-}\right)$, nitrate $\left(\mathrm{NO}_{3}^{-}\right)$and iodide anions $\left(\mathrm{I}^{-}\right)$in the $\mathrm{ESI}(-)$ spectra.

fate, sodium taurocholate hydrate and Ultramark 1621 in the negative mode. The ion mobility measurements were calibrated using tetrabutyl ammonium chloride as the instrument standard and 2,4-lutidine as the mobility standard (Zhang et al., 2016b). The average IMS $\left(t / \mathrm{d} t_{50}\right)$ and MS $\left(m / \mathrm{d} m_{50}\right)$ resolving powers are $\sim 80$ and $\sim 4000$, respectively. Mass spectra and ion mobility spectra were collected by Aquility DAQ v2.1.0 and post-processed by Tofware v2.5.3.

\section{Results and discussion}

\subsection{Ion adduct formation}

The strong electron affinity of the $-\mathrm{ONO}_{2}$ functional group makes alkyl nitrate a potential candidate for being analyzed in the $\operatorname{ESI}(-)$ negative electrospray ionization mode. However, the ESI(-) mass spectra of the AN standards investigated here are typically characterized by various fragments and clusters due principally to the thermally labile $-\mathrm{ONO}_{2}$ moiety. As shown in Fig. 1, no molecular ion $\left([\mathrm{M}]^{-}\right.$or $\left.[\mathrm{M}-\mathrm{H}]^{-}\right)$is observed in the $\operatorname{ESI}(-)$ mass spectra of 1 mononitroglycerin (MNG), 1,3-dinitroglycerin (DNG) and pentaerythritol tetranitrate (PETN). Instead, a small peak ap- 

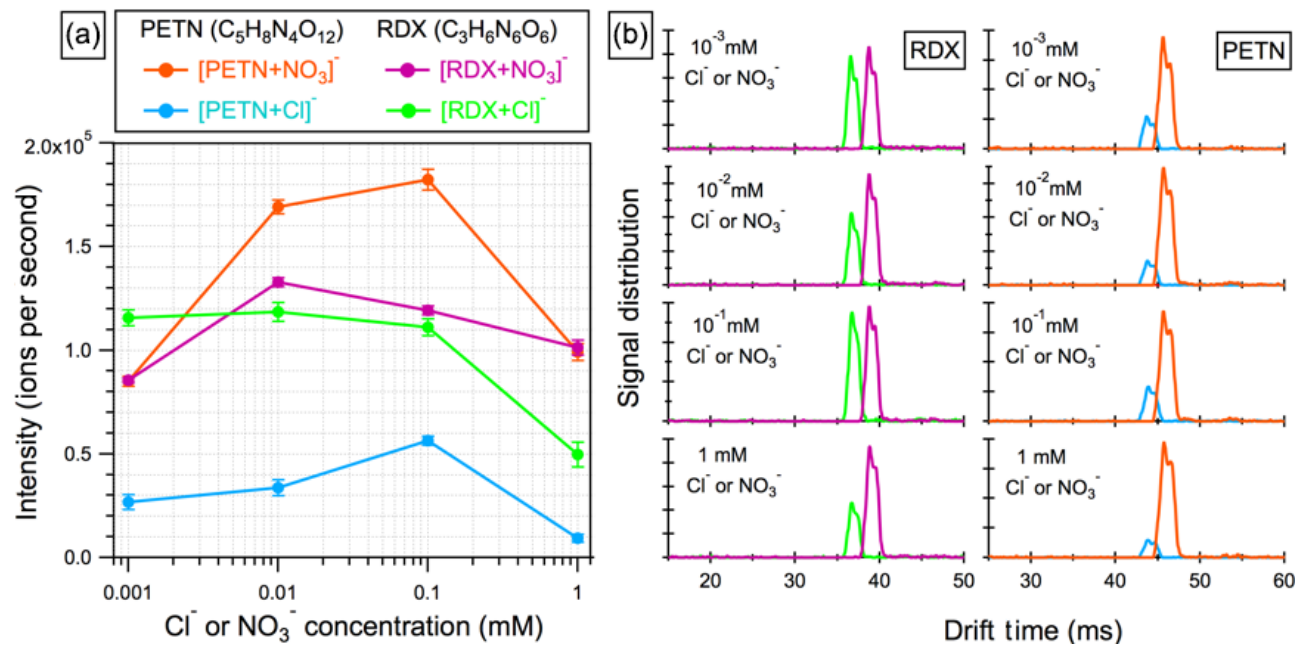

Figure 2. (a) Signals of the ion adducts produced from RDX and PETN by clustering with chloride $\left(\mathrm{Cl}^{-}\right)$and nitrate $\left(\mathrm{NO}_{3}^{-}\right)$as a function of the corresponding anion concentrations ranging from $1 \mu \mathrm{M}$ to $1 \mathrm{mM}$. (b) Drift-time distributions of the ion adducts $[\mathrm{RDX}+\mathrm{Cl}]^{-},[\mathrm{PETN}+$ $\mathrm{Cl}]^{-},\left[\mathrm{RDX}+\mathrm{NO}_{3}\right]^{-}$and $\left[\mathrm{PETN}+\mathrm{NO}_{3}\right]^{-}$are consistent at different anion concentrations.

pears as a cluster ion of the form $\left[\mathrm{M}+\mathrm{NO}_{2}-\mathrm{H}\right]^{-}$. It is worth noting that the addition of water to the mobile phase does not promote the molecular ion formation; rather significant nitrate losses via hydrolysis were observed. With the addition of trace amount of salts, i.e., ammonium chloride $\left(\mathrm{NH}_{4} \mathrm{Cl}\right)$, sodium nitrate $\left(\mathrm{NaNO}_{3}\right)$, sodium iodide (NaI) and ammonium acetate $\left(\mathrm{NH}_{4} \mathrm{Ac}\right)$, the overall signal intensities were significantly enhanced through the production of a suite of adduct ions of the form $[\mathrm{M}+\mathrm{Cl}]^{-},\left[\mathrm{M}+\mathrm{NO}_{3}\right]^{-},[\mathrm{M}+\mathrm{I}]^{-}$and $[\mathrm{M}+\mathrm{Ac}]^{-}$, respectively. The relative sensitivities of individual adduct ions increase by ultimately 2 orders of magnitude compared with the pure standard in a methanol solution. Here the observed ion adduct formation in ESI can be considered to be a special case of chemical ionization occurring in the solution before the charge separation process takes place.

Table 1 lists the characteristic adduct ions formed from three AN standards (MNG, DNG and PETN) in a methanol solution with selected additives $\left(\mathrm{NH}_{4} \mathrm{Ac}, \mathrm{NH}_{4} \mathrm{Cl}, \mathrm{NaI}\right.$ and $\mathrm{NaNO}_{3}$ ). Ion adducts are systematically observed from all of the ANs investigated regardless of the number of $-\mathrm{ONO}_{2}$ functional groups attached to the molecule. Nitrate $\left(\mathrm{NO}_{3}^{-}\right)$ and chloride $\left(\mathrm{Cl}^{-}\right)$anions were found to be the most effective additives for promoting ion adduct formation. Nitrate clusters exhibit the highest signal intensity and lowest limit of detection, especially for the poly-nitrates and functionalized alkyl nitrates investigated. Chloride clusters are characterized by two distinct ions with a mass difference of $2 \mathrm{amu}$ and abundance ratio of $3: 1$ due to the natural presence of isotopes ${ }^{35} \mathrm{Cl}$ and ${ }^{37} \mathrm{Cl}$. Also given in Table 1 are the detected negative ions from two organic nitro-compounds, i.e., hexahydro-1,3,5-trinitro-1,3,5-triazine (RDX) and 2,4dinitrotoluene (DNT). In contrast to RDX, which undergoes intensive clustering processes with $\mathrm{Cl}^{-}, \mathrm{I}^{-}$and $\mathrm{NO}_{3}^{-}$during negative ESI, one dominant molecular ion $\left(\left[\mathrm{M}-\mathrm{H}^{-}\right)\right.$

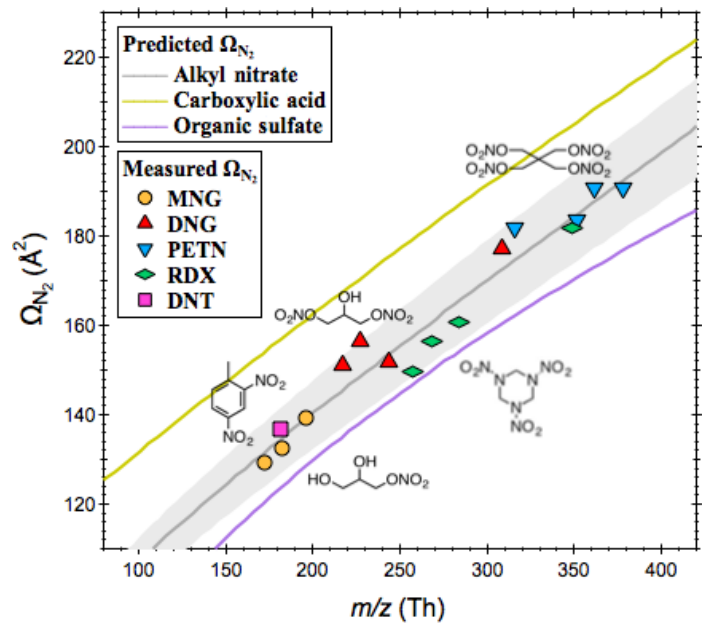

Figure 3. Measured collision cross sections $\left(\Omega_{N_{2}}\right)$ of the AN ion adducts as a function of their mass-to-charge ratios appear along the predicted $\Omega_{N_{2}}-m / z$ trend line. Also shown here are the predicted $\Omega_{N_{2}}-m / z$ trend lines for carboxylic acids and organic sulfates, which are major chemical classes of atmospheric interest detected in the negative ESI mode.

was observed in the ESI(-) mass spectra of DNT. The limits of detection (LODs) towards the nitrate adducts are in the range of 0.1 to $4.3 \mu \mathrm{M}$ (see Table 1), demonstrating an improved performance of the IMS-MS technique employed here compared with literature data obtained from sprayed solutions (Asbury et al., 2000; Hilton et al., 2010). For example, the LODs for DNT and RDX are 26 and $40 \mu \mathrm{g} \mathrm{L}-1$, respectively, in Asbury et al. (2000), and the LOD for urea nitrate is $2.5 \mathrm{mg} \mathrm{L}^{-1}$ in Hilton et al. (2010). 
Table 1. Overview of compounds containing $-\mathrm{ONO}_{2}$ and $-\mathrm{NO}_{2}$ functional groups investigated in this study.

\begin{tabular}{|c|c|c|c|c|c|c|}
\hline \multirow[t]{2}{*}{ Compound } & \multirow{2}{*}{$\begin{array}{l}\text { Molecular } \\
\text { formula }\end{array}$} & \multicolumn{2}{|l|}{ Ion } & \multirow{2}{*}{$\begin{array}{l}\mathrm{LOD}^{\mathrm{a}} \\
(\mu \mathrm{M})\end{array}$} & \multirow{2}{*}{$\begin{array}{r}\Omega_{\mathrm{N}_{2}}{ }^{\mathrm{b}} \\
\left(\AA^{2}\right)\end{array}$} & \multirow[t]{2}{*}{ Structure } \\
\hline & & Formula & $m / z$ & & & \\
\hline \multirow{3}{*}{$\begin{array}{l}\text { 1-Mononitroglycerin } \\
\text { (MNG) }\end{array}$} & \multirow{3}{*}{$\mathrm{C}_{3} \mathrm{H}_{7} \mathrm{NO}_{5}$} & {$[\mathrm{M}+\mathrm{Cl}]^{-}$} & 172.0 & 0.8 & 129.4 & \multirow{3}{*}{$\stackrel{\mathrm{OH}}{\mathrm{HONO}}_{2}$} \\
\hline & & {$\left[\mathrm{M}+\mathrm{NO}_{2}-\mathrm{H}\right]^{-}$} & 182.0 & 0.7 & 132.7 & \\
\hline & & {$[\mathrm{M}+\mathrm{Ac}]^{-}$} & 196.0 & 0.3 & 139.2 & \\
\hline \multirow{4}{*}{$\begin{array}{l}\text { 1,3-Dinitroglycerin } \\
(\mathrm{DNG})\end{array}$} & \multirow{4}{*}{$\mathrm{C}_{3} \mathrm{H}_{6} \mathrm{~N}_{2} \mathrm{O}_{7}$} & {$[\mathrm{M}+\mathrm{Cl}]^{-}$} & 217.0 & 1.1 & 151.1 & \multirow{4}{*}{$\mathrm{O}_{2} \mathrm{NO} \mathrm{OH}_{\mathrm{ONC}}^{\mathrm{H}}$} \\
\hline & & {$\left[\mathrm{M}+\mathrm{NO}_{2}-\mathrm{H}\right]^{-}$} & 227.0 & 4.3 & 156.6 & \\
\hline & & {$\left[\mathrm{M}+\mathrm{NO}_{3}\right]^{-}$} & 244.0 & 0.6 & 151.7 & \\
\hline & & {$[\mathrm{M}+\mathrm{I}]^{-}$} & 308.9 & 0.8 & 177.0 & \\
\hline \multirow{6}{*}{$\begin{array}{l}\text { Pentaerythritol tetranitrate } \\
\text { (PETN) }\end{array}$} & \multirow[t]{6}{*}{$\mathrm{C}_{5} \mathrm{H}_{8} \mathrm{~N}_{4} \mathrm{O}_{12}$} & {$[\mathrm{M}-\mathrm{H}]^{-}$} & 315.0 & 1.1 & 181.7 & \multirow{6}{*}{$\mathrm{O}_{2} \mathrm{NO}-<-\mathrm{ONC}$} \\
\hline & & {$[\mathrm{M}+\mathrm{Cl}]^{-}$} & 351.0 & 0.5 & 183.7 & \\
\hline & & {$\left[\mathrm{M}+\mathrm{NO}_{2}-\mathrm{H}\right]^{-}$} & 361.0 & 0.9 & 190.7 & \\
\hline & & {$\left[\mathrm{M}+\mathrm{NO}_{3}\right]^{-}$} & 378.0 & 0.2 & 190.9 & \\
\hline & & {$[\mathrm{M}+\mathrm{I}]^{-}$} & 442.9 & 0.1 & 216.2 & \\
\hline & & {$[2 \mathrm{M}+\mathrm{Cl}]^{-}$} & 667.0 & 1.0 & 262.6 & \\
\hline $\begin{array}{l}\text { 2,4-Dinitrotoluene } \\
(\mathrm{DNT})\end{array}$ & $\mathrm{C}_{7} \mathrm{H}_{6} \mathrm{~N}_{2} \mathrm{O}_{4}$ & {$[\mathrm{M}-\mathrm{H}]^{-}$} & 181.0 & 0.6 & 137.0 & $U_{2}$ \\
\hline \multirow{5}{*}{$\begin{array}{l}\text { Hexahydro-1,3,5-trinitro-1,3,5- } \\
\text { triazine (RDX) }\end{array}$} & \multirow[t]{5}{*}{$\mathrm{C}_{3} \mathrm{H}_{6} \mathrm{~N}_{6} \mathrm{O}_{6}$} & {$[\mathrm{M}+\mathrm{Cl}]^{-}$} & 257.0 & 0.3 & 149.8 & \multirow{5}{*}{$\overbrace{\substack{\mathrm{N}^{\prime} \\
\mathrm{NO}_{2}}}^{\mathrm{O}_{2} \mathrm{~N}_{2}}{ }^{\mathrm{N}}$} \\
\hline & & {$\left[\mathrm{M}+\mathrm{NO}_{2}-\mathrm{H}\right]^{-}$} & 267.1 & 1.4 & 156.3 & \\
\hline & & {$\left[\mathrm{M}+\mathrm{NO}_{3}\right]^{-}$} & 284.0 & 0.2 & 160.8 & \\
\hline & & {$[\mathrm{M}+\mathrm{I}]^{-}$} & 348.9 & 0.1 & 181.9 & \\
\hline & & {$[2 \mathrm{M}+\mathrm{Cl}]^{-}$} & 479.0 & 1.6 & 203.5 & \\
\hline
\end{tabular}

a The limit of detection (LOD) is calculated as LOD $=\sigma \times(S / N) / k$, where $S / N$ is the signal-to-noise ratio, which is taken as 3 here, $k$ is the response factor of IMS-MS towards individual ion adducts produced from $5 \mu \mathrm{M}$ standard nitrate solution during negative ESI and $\sigma$ is the standard deviation of the IMS-MS response over the course of 60 s measurements. ${ }^{b}$ The collision cross section $\left(\Omega_{\mathrm{N}_{2}}\right)$ is calculated through the modified zero field (so called Mason-Schamp) equation; see more details in Zhang et al. (2016b).

The effect of the additive concentrations $\left(\mathrm{NO}_{3}^{-}\right.$and $\left.\mathrm{Cl}^{-}\right)$ on the ion adduct formation was investigated using an equimolar mixture ( $5 \mu \mathrm{M}$ each) of PETN and RDX as a representative of nitrates and nitro-compounds, respectively, in a methanol solution (Fig. 2). In the absence of any additives, the presence of background anions from either impurities in the solvent or thermal decomposition of alkyl nitrates leads to a detectable amount of ion adducts. With the anion levels on the order of micromoles, ion adducts become dominant in the ESI(-) mass spectra. The optimal anion concentration was found to be in the range of 0.01 to $0.1 \mathrm{mM}$. Progressively rising anion concentrations $(>1 \mathrm{mM})$ essentially suppress adduct formation due to the competition for limited resources, such as space and charge (Cech and Enke, 2001). Note that the measured drift time for each ion adduct is constant at anion concentrations ranging from $1 \mu \mathrm{M}$ to $1 \mathrm{mM}$, indicative of the absence of ion-molecule clustering in the IMS drift tube.

\subsection{Trend line of collision cross section vs. mass-to-charge ratio}

The collision cross section $\left(\Omega_{\mathrm{N}_{2}}\right)$ represents the effective area for interactions between a charged molecule and the surrounding buffer gases (e.g., $\mathrm{N}_{2}$ herein). It is derived from the mobility measurement in the IMS drift tube, where ions with open conformation undergo more collisions with buffer gas molecules and hence travel more slowly than the compact ones (Shvartsburg et al., 2000). The measured $\Omega_{\mathrm{N}_{2}}$ for organic nitrates and nitro-compounds given in Table 1 is in good agreement with previous reported values obtained from experiments where the analytes were introduced into the IMS system from the vapor phase (Kaur-Atwal et al., 2009; Kozole et al., 2015). Combination of the collision cross section with molecular mass (as denoted by mass-to-charge ratio, $m / z$ ) provides a two-dimensional space for separation of species based on their size as well as geometry. We have shown that species of the same chemical class (e.g., amines, alcohols and carboxylic acids) tend to situate as a narrow band and follow a unique trend line on the 2-D space (Zhang et al., 2016b). Here we demonstrate the presence of a $\Omega_{\mathrm{N}_{2}}$ $\mathrm{m} / \mathrm{z}$ trend line for alkyl nitrates. Figure 3 shows that the mea- 

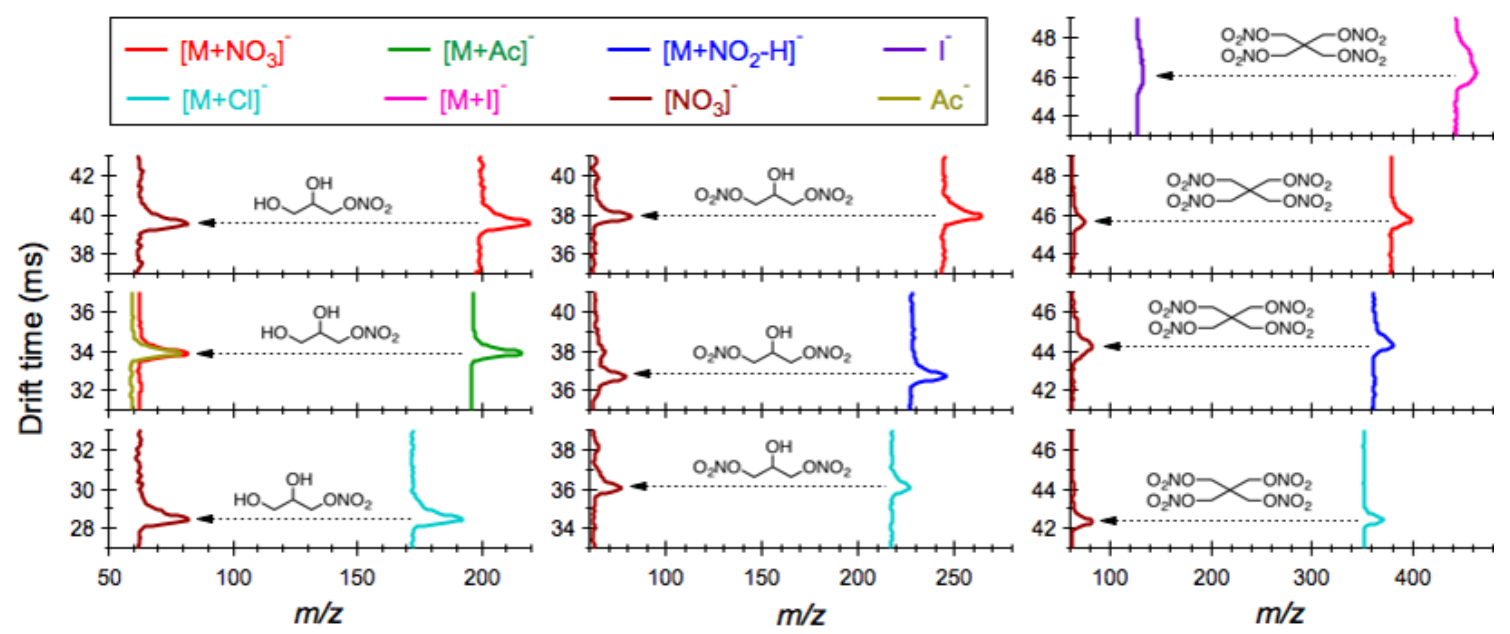

Figure 4. Characteristic fragment ions produced from MNG, DNG and PETN by clustering with acetate $\left(\mathrm{Ac}^{-}\right)$, chloride $\left(\mathrm{Cl}^{-}\right)$, iodide $\left(\mathrm{I}^{-}\right)$, nitrate $\left(\mathrm{NO}_{3}^{-}\right)$and nitrite $\left(\mathrm{NO}_{2}^{-}\right)$upon collision-induced dissociation performed at a CID voltage of $20 \mathrm{~V}$.

sured $\Omega_{\mathrm{N}_{2}}$ of the AN adducts, regardless of the AN molecular structures and types of anions that promote the adduct formation, appears along the $\Omega_{\mathrm{N}_{2}}-m / z$ trend line predicted by the core model (deviations less than 5.2\%). Also shown here are the predicted $\Omega_{\mathrm{N}_{2}}-m / z$ trend lines for mono-carboxylic or multi-carboxylic acids and organic sulfates, which readily produce molecular ions via deprotonation $\left([\mathrm{M}-\mathrm{H}]^{-}\right)$during negative ESI. Alkyl nitrates can be distinguished from carboxylic acids and sulfates based on their distinct relationship of collision cross sections to the mass-to-charge ratio. Note that other important chemical classes of atmospheric interest, such as amines, alcohols, aldehydes and peroxides, are suitable for analysis in the positive ESI, and their trend lines are not given here.

\subsection{Characteristic fragments upon collision-induced dissociation}

Molecular structures of selected AN ion adducts were further probed with the assistance of the CID analysis, which was performed after the drift tube but prior to the time-of-flight chamber. The resulting daughter ion appears at the same drift time as the parent ion, allowing for a straightforward correlation of any given ion with its fragments. As shown in Fig. 4, the nitrate ion $\left(\mathrm{NO}_{3}^{-}\right)$at $m / z 62$ is exclusively observed upon CID of the parent ion adducts formed from MNG, DNG and PETN by clustering with $\mathrm{Cl}^{-}, \mathrm{NO}_{3}^{-}$and $\mathrm{Ac}^{-}$. The $\mathrm{NO}_{3}^{-}$ fragment resulting from decomposition of the corresponding parent ion adduct can be well separated from that originally added to the AN solution based on their entirely different ion mobilities (as reflected by the measured drift time). Thus $\mathrm{NO}_{3}^{-}$is considered to be a characteristic fragment upon CID of the parent AN adduct ion and serves as a tracer to verify the presence of the $-\mathrm{ONO}_{2}$ functional group in unknown compounds.
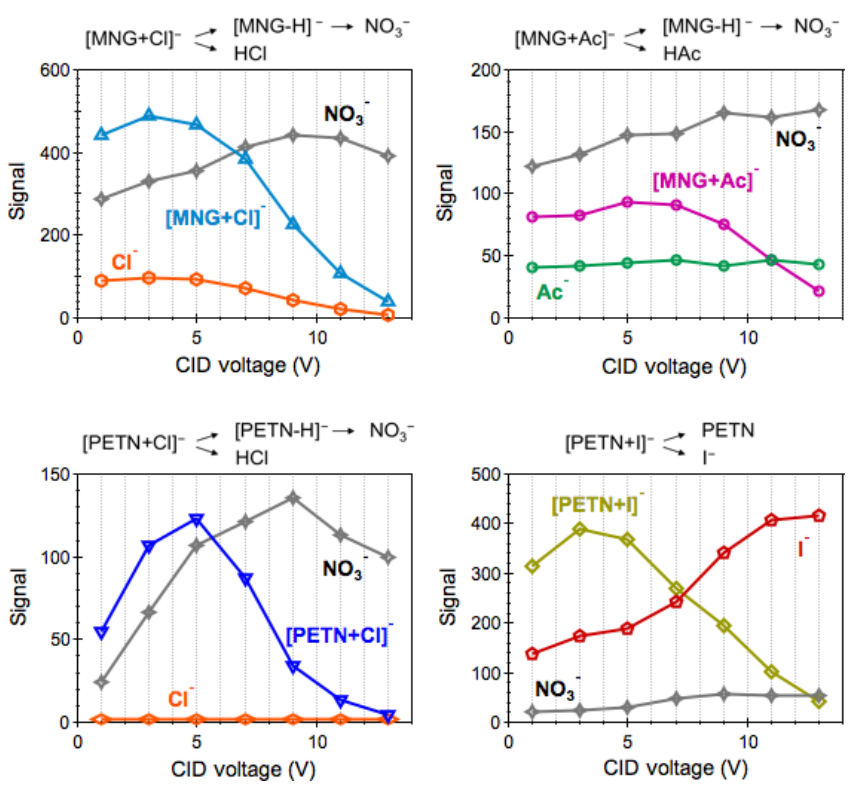

Figure 5. Peak intensities of the precursor ion adducts $[\mathrm{MNG}+$ $\mathrm{Cl}]^{-},[\mathrm{MNG}+\mathrm{Ac}]^{-},[\mathrm{PETN}+\mathrm{Cl}]^{-}$and $[\mathrm{PETN}+\mathrm{I}]^{-}$as well as their fragment ions as a function of the collision energy as displayed by the CID voltage.

The anions $\left(\mathrm{Cl}^{-}, \mathrm{NO}_{3}^{-}\right.$and $\left.\mathrm{Ac}^{-}\right)$that promote the clustering chemistry were not observed upon CID of the parent AN adducts. Figure 5 shows the profiles of four ion adducts, i.e., $[\mathrm{MNG}+\mathrm{Cl}]^{-},[\mathrm{MNG}+\mathrm{Ac}]^{-},[\mathrm{PETN}+\mathrm{Cl}]^{-}$ and $[\text { PETN }+\mathrm{I}]^{-}$, as well as their resulting fragments under a sequence of the CID potential gradient. As expected, the abundance of the transmitted parent ion adducts decreases as the CID voltage rises. $\mathrm{NO}_{3}^{-}$appears as the largest product ion, and its enhanced abundance with increasing CID voltage is balanced by the decrease in signals of the correspond- 
ing parent ion adduct. $\mathrm{Cl}^{-}$and $\mathrm{Ac}^{-}$remain minor peaks over the entire range of the displayed CID potential gradient. Under low-energy collisions, the parent AN ion adduct principally follows two fragmentation pathways, leading to $\mathrm{Cl}^{-} / \mathrm{Ac}^{-} / \mathrm{I}^{-}$with the neutral AN molecule or the deprotonated AN molecular ion $\left([\mathrm{M}-\mathrm{H}]^{-}\right)$via the neutral loss of $\mathrm{HCl} / \mathrm{HAc} / \mathrm{HI}$. The absence of $\mathrm{Cl}^{-}$and $\mathrm{Ac}^{-}$indicates higher gas-phase basicity of $\mathrm{Cl}^{-} / \mathrm{Ac}^{-}$than $[\mathrm{M}-\mathrm{H}]^{-}$. As a result, the mechanism yielding $[\mathrm{M}-\mathrm{H}]^{-}$is the dominant fragmentation pathway of AN ion adducts (with the exception of $[\mathrm{PETN}+\mathrm{I}]^{-}$). The resulting molecular ion $[\mathrm{M}-\mathrm{H}]^{-}$decomposes promptly to $\mathrm{NO}_{3}^{-}$due to the presence of the fragile $\mathrm{R}-\mathrm{ONO}_{2}$ bond.

\subsection{Application to isoprene SOA}

The $\mathrm{OH}$-initiated oxidation of isoprene produces a population of isoprene peroxy radicals $\left(\mathrm{RO}_{2}\right)$, the fate of which depends on the level of nitric oxide. Under high-NO conditions as performed in the chamber experiments here, $\mathrm{RO}_{2}$ radicals preferentially react with $\mathrm{NO}$, leading to major firstgeneration products including isoprene hydroxy nitrates, among which the two $\beta$-hydroxy nitrates dominate the isomer distribution. Due to the presence of a double bond, the hydroxy nitrate could undergo $\mathrm{OH}$ addition followed again by reactions of $\mathrm{RO}_{2}$ radicals with $\mathrm{NO}$, leading to a spectrum of products, of which some highly functionalized molecules such as the dihydroxy dinitrate are potential SOA precursors (Wennberg et al., 2018).

A pair of ion adducts at $m / z 261\left(\left[\mathrm{M}+{ }^{35} \mathrm{Cl}\right]^{-}\right)$and $m / z 263\left(\left[\mathrm{M}+{ }^{37} \mathrm{Cl}\right]^{-}\right)$with the abundance ratio of $3: 1$ is observed in the mass spectra of the isoprene SOA extracts in methanol with $0.2 \mathrm{mM}$ sodium chloride as the additive. These two adducts share an identical mobility (DT $=\sim$ $25.8 \mathrm{~ms}$ ), which also appears as a small peak (DT $=\sim$ $25.7 \mathrm{~ms}$ ) in the mobility spectra of the $\mathrm{NO}_{3}^{-}$ion (Fig. 6c). Further inspection of the "mobility-selected" mass spectra of the parent ion adduct at $m / z 261$ reveals that $\mathrm{NO}_{3}^{-}$is the major fragment ion (Fig. 6a). With the application of a CID potential sequence, the intensity of the precursor ion at $\mathrm{m} / \mathrm{z} 261$ decreases and that of the fragment ion at $\mathrm{m} / \mathrm{z}$ 62 increases (Fig. 6b), a similar pattern to that observed for the AN standards. We thereby tentatively assign the parent ion adduct at $m / z 261$ to a second-generation oxidation product, dihydroxy dinitrate $\left(\mathrm{C}_{5} \mathrm{H}_{10} \mathrm{O}_{8} \mathrm{~N}_{2}\right.$; see the chemical structure given in Fig. 6), which is produced from the addition of $\mathrm{OH}$ to the two double bonds of isoprene followed by $\mathrm{RO}_{2}+\mathrm{NO}$ reactions. It is interesting to note that a small shoulder peak appears at $\sim 26.0 \mathrm{~ms}$ in the mobility spectra of the ion adduct at $m / z 261$ (Fig. 6c), likely representative of the $\mathrm{C}_{5} \mathrm{H}_{10} \mathrm{O}_{8} \mathrm{~N}_{2}$ isomers generated from the much less favored $\mathrm{OH}$-addition channels that produce primary $\mathrm{RO}_{2}$ radicals. Quantitative analysis of the dihydroxy dinitrate is complicated by the matrix interference during the ESI process, and chromatographic separation prior to infusion to the ESI
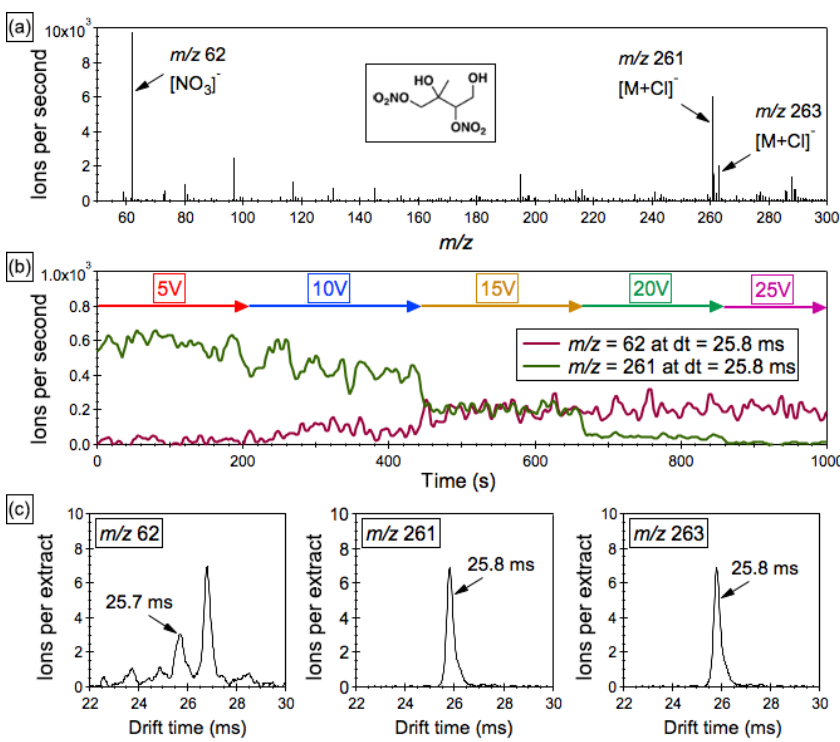

Figure 6. (a) The "mobility-selected" mass spectra of the parent ion adduct at $m / z 261$ and its major fragment at $m / z 62$ in isoprene SOA extracts with $\sim 0.2 \mathrm{mM}$ sodium chloride as the additive. (b) Profiles of the precursor ion adduct at $\mathrm{m} / \mathrm{z} 261$ and its product ion at $m / z 62$ as a function of the CID voltage. (c) Drift-time spectra of the ion adduct at $m / z 261$, its isotope ion adduct at $m / z 263$ and the fragment ion at $m / z 62$.

source is required (Zhang et al., 2015a, 2016a), which is beyond the capability of the current instrument setup. Also note that first-generation hydroxy nitrates were not detected due to their relatively high volatility and thus quite limited partitioning onto the particle phase. On the other hand, multiple peaks were observed in the mobility spectra of the $\mathrm{NO}_{3}^{-}$ion (Fig. 6c), and their drift times are higher than that of the ion assigned to the dihydroxy dinitrate, implying that some highmolecular-weight nitrate products were likely fragmented in the quadrupole interface.

\section{Conclusions}

The anion attachment chemistry was previously used in the negative ESI operation to effectively induce ion formation from neutral molecules that lack acidic sites (Zhu and Cole, 2000). Here we build on the use of anion attachment, a special chemical ionization mechanism in the solution, to characterize the condensed-phase alkyl nitrates at the molecular level. The propensity of the $-\mathrm{ONO}_{2}$ moiety to cluster with a diverse selection of anions, including $\mathrm{Cl}^{-}, \mathrm{I}^{-}, \mathrm{NO}_{3}^{-}$ and $\mathrm{Ac}^{-}$, was observed during the negative electrospray ionization process, and the measured total ion signals were enhanced by ultimately 2 orders of magnitude. Compared with conventional mass spectrometric techniques, the coupled ion mobility and mass-to-charge-ratio measurements provide a two-dimensional separation of alkyl nitrates from 
other chemical classes commonly detected in negative ESI, such as organic sulfates and carboxylic acids. With the assistance of the collision-induced dissociation analysis, upon which the resulting product ions share the identical drift time as the precursor ion, molecular structures of ANs can be further probed. Regardless of the types of anions attached to the AN molecules, dissociation of the parent adduct ion yields a characteristic fragment, $\mathrm{NO}_{3}^{-}$at $m / z 62$, which can be used to verify the presence of the - $-\mathrm{ONO}_{2}$ functional group in any given molecule. These new features enable the unambiguous identification of alkyl nitrates in a complex organic mixture, as exemplified by the detection of hydroxynitrates in isoprene derived SOA. The IMS-MS technique for the measurement of condensed-phase ANs is in its early stages of development. Accurate quantification of a given AN molecule by minimizing the ion suppression and improving the longterm stability of ESI is needed for future work.

Data availability. Data presented in this paper are available upon request to the corresponding author, Xuan Zhang (xuanz@ucar.edu).

Author contributions. XZ, GST, JJO, JTJ, DRW and MRC designed the research; XZ, HZ, WX and XW performed the research; XZ, HZ, WX, XW, JTJ, DRW and MRC analyzed data; and XZ, GST, JJO and MRC wrote the paper.

Competing interests. The authors declare that they have no conflict of interest.

Acknowledgements. The National Center for Atmospheric Research is operated by the University Corporation for Atmospheric Research, under the sponsorship of the National Science Foundation.

Financial support. This research has been supported by the National Science Foundation.

Review statement. This paper was edited by Pierre Herckes and reviewed by two anonymous referees.

\section{References}

Asbury, G. R., Klasmeier, J., and Hill Jr, H. H.: Analysis of explosives using electrospray ionization/ion mobility spectrometry (ESI/IMS), Talanta, 50, 1291-1298, 2000.

Atlas, E.: Evidence for $=\mathrm{C} 3$ alkyl nitrates in rural and remote atmospheres, Nature, 331, 426-428, 1988.

Beaver, M. R., Clair, J. M. St., Paulot, F., Spencer, K. M., Crounse, J. D., LaFranchi, B. W., Min, K. E., Pusede, S. E., Wooldridge, P.
J., Schade, G. W., Park, C., Cohen, R. C., and Wennberg, P. O.: Importance of biogenic precursors to the budget of organic nitrates: observations of multifunctional organic nitrates by CIMS and TD-LIF during BEARPEX 2009, Atmos. Chem. Phys., 12, 5773-5785, https://doi.org/10.5194/acp-12-5773-2012, 2012.

Brown, S. S., deGouw, J. A., Warneke, C., Ryerson, T. B., Dubé, W. P., Atlas, E., Weber, R. J., Peltier, R. E., Neuman, J. A., Roberts, J. M., Swanson, A., Flocke, F., McKeen, S. A., Brioude, J., Sommariva, R., Trainer, M., Fehsenfeld, F. C., and Ravishankara, A. R.: Nocturnal isoprene oxidation over the Northeast United States in summer and its impact on reactive nitrogen partitioning and secondary organic aerosol, Atmos. Chem. Phys., 9, 30273042, https://doi.org/10.5194/acp-9-3027-2009, 2009.

Cappa, C. D., Zhang, X., Loza, C. L., Craven, J. S., Yee, L. D., and Seinfeld, J. H.: Application of the Statistical Oxidation Model (SOM) to Secondary Organic Aerosol formation from photooxidation of C12 alkanes, Atmos. Chem. Phys., 13, 1591-1606, https://doi.org/10.5194/acp-13-1591-2013, 2013.

Cech, N. B. and Enke, C. G.: Practical implications of some recent studies in electrospray ionization fundamentals, Mass Spectrom. Rev., 20, 362-387, 2001.

Cotte-Rodríguez, I., Takáts, Z., Talaty, N., Chen, H., and Cooks, R. G.: Desorption electrospray ionization of explosives on surfaces: sensitivity and selectivity enhancement by reactive desorption electrospray ionization, Anal. Chem., 77, 6755-6764, 2005.

Crawford, C. L. and Hill, H. H.: Comparison of reactant and analyte ions for 63Nickel, corona discharge, and secondary electrospray ionization sources with ion mobility-mass spectrometry, Talanta, 107, 225-232, 2013.

Day, D. A., Wooldridge, P. J., Dillon, M. B., Thornton, J. A., and Cohen, R. C.: A thermal dissociation laserainduced fluorescence instrument for in situ detection of $\mathrm{NO}_{2}$, peroxy nitrates, alkyl nitrates, and $\mathrm{HNO}_{3}$, J. Geophys. Res.-Atmos., 107, D64046, https://doi.org/10.1029/2001JD000779, 2002.

Farmer, D. K., Matsunaga, A., Docherty, K. S., Surratt, J. D., Seinfeld, J. H., Ziemann, P. J., and Jimenez, J. L.: Response of an aerosol mass spectrometer to organonitrates and organosulfates and implications for atmospheric chemistry, P. Natl. Acad. Sci. USA, 107, 6670-6675, 2010.

Farmer, D. K., Perring, A. E., Wooldridge, P. J., Blake, D. R., Baker, A., Meinardi, S., Huey, L. G., Tanner, D., Vargas, O., and Cohen, R. C.: Impact of organic nitrates on urban ozone production, Atmos. Chem. Phys., 11, 4085-4094, https://doi.org/10.5194/acp11-4085-2011, 2011.

Groessl, M., Graf, S., and Knochenmuss, R.: High resolution ion mobility-mass spectrometry for separation and identification of isomeric lipids, Analyst, 140, 6904-6911, 2015.

He, S., Chen, Z., and Zhang, X.: Photochemical reactions of methyl and ethyl nitrate: a dual role for alkyl nitrates in the nitrogen cycle, Environ. Chem., 8, 529-542, 2011.

He, S. Z., Chen, Z. M., Zhang, X., Zhao, Y., Huang, D. M., Zhao, J. N., Zhu, T., Hu, M., and Zeng, L. M.: Measurement of atmospheric hydrogen peroxide and organic peroxides in Beijing before and during the 2008 Olympic Games: Chemical and physical factors influencing their concentrations, J. Geophys. Res.Atmos., 115, D17307, https://doi.org/10.1029/2009JD013544, 2010.

Hilton, C. K., Krueger, C. A., Midey, A. J., Osgood, M., Wu, J., and Wu, C.: Improved analysis of explosives samples with electro- 
spray ionization-high resolution ion mobility spectrometry (ESIHRIMS), Int. J. Mass Spec., 298, 64-71, 2010.

Huang, D. D., Zhang, X., Dalleska, N. F., Lignell, H., Coggon, M. M., Chan, C. M., Flagan, R. C., Seinfeld, J. H., and Chan, C. K.: A note on the effects of inorganic seed aerosol on the oxidation state of secondary organic aerosol- $\alpha$-pinene ozonolysis, J. Geophys. Res.-Atmos., 121, 12476-12483, 2016.

Huang, Y., Zhao, R., Charan, S. M., Kenseth, C. M., Zhang, X., and Seinfeld, J. H.: Unified theory of vapor-wall mass transport in Teflon-walled environmental chambers, Environ. Sci. Technol., 52, 2134-2142, 2018.

Justes, D. R., Talaty, N., Cotte-Rodriguez, I., and Cooks, R. G.: Detection of explosives on skin using ambient ionization mass spectrometry, Chem. Commun., 21, 2142-2144, 2007.

Kaplan, K., Graf, S., Tanner, C., Gonin, M., Fuhrer, K., Knochenmuss, R., Dwivedi, P., and Hill Jr, H. H.: Resistive Glass IMTOFMS, Anal. Chem., 82, 9336-9343, 2010.

Kaur-Atwal, G., O’Connor, G., Aksenov, A. A., Bocos-Bintintan, V., Thomas, C. L. P., and Creaser, C. S.: Chemical standards for ion mobility spectrometry: a review, International Journal for Ion Mobility Spectrometry, 12, 1-14, 2009.

Kiendler-Scharr, A., Mensah, A. A., Friese, E., Topping, D., Nemitz, E., Prevot, A. S. H., Äijälä, M., Allan, J., Canonaco, F., and Canagaratna, M.: Ubiquity of organic nitrates from nighttime chemistry in the European submicron aerosol, Geophys. Res. Lett., 43, 7735-7744, 2016.

Kozole, J., Levine, L. A., Tomlinson-Phillips, J., and Stairs, J. R.: Gas phase ion chemistry of an ion mobility spectrometry based explosive trace detector elucidated by tandem mass spectrometry, Talanta, 140, 10-19, 2015.

Krechmer, J. E., Coggon, M. M., Massoli, P., Nguyen, T. B., Crounse, J. D., Hu, W., Day, D. A., Tyndall, G. S., Henze, D. K., Rivera-Rios, J. C., Nowak, J. B., Kimmel, J. R., III, R. L. M., Stark, H., Jayne, J. T., Sipila, M., Junninen, H., Clair, J. M. S., Zhang, X., Feiner, P. A., Zhang, L., Miller, D. O., Brune, W. H., Keutsch, F. N., Wennberg, P. O., Seinfeld, J. H., Worsnop, D. R., Jimenez, J. L., and Canagaratna, M. R.: Formation of low volatility organic compounds and secondary organic aerosol from isoprene hydroxyhydroperoxide low-NO oxidation, Environ. Sci. Technol., 49, 10330-10339, 2015.

Krechmer, J. E., Groessl, M., Zhang, X., Junninen, H., Massoli, P., Lambe, A. T., Kimmel, J. R., Cubison, M. J., Graf, S., Lin, Y.-H., Budisulistiorini, S. H., Zhang, H., Surratt, J. D., Knochenmuss, R., Jayne, J. T., Worsnop, D. R., Jimenez, J.-L., and Canagaratna, M. R.: Ion mobility spectrometry-mass spectrometry (IMS-MS) for on- and offline analysis of atmospheric gas and aerosol species, Atmos. Meas. Tech., 9, 3245-3262, https://doi.org/10.5194/amt-9-3245-2016, 2016.

Lambe, A., Massoli, P., Zhang, X., Canagaratna, M., Nowak, J., Daube, C., Yan, C., Nie, W., Onasch, T., Jayne, J., Kolb, C., Davidovits, P., Worsnop, D., and Brune, W.: Controlled nitric oxide production via $\mathrm{O}\left({ }^{1} \mathrm{D}\right)+\mathrm{N}_{2} \mathrm{O}$ reactions for use in oxidation flow reactor studies, Atmos. Meas. Tech., 10, 2283-2298, https://doi.org/10.5194/amt-10-2283-2017, 2017.

Lee, B. H., Mohr, C., Lopez-Hilfiker, F. D., Lutz, A., Hallquist, M., Lee, L., Romer, P., Cohen, R. C., Iyer, S., and Kurtén, T.: Highly functionalized organic nitrates in the southeast United States: Contribution to secondary organic aerosol and reactive nitrogen budgets, P. Natl. Acad. Sci. USA, 113, 1516-1521, 2016.
Loza, C. L., Craven, J. S., Yee, L. D., Coggon, M. M., Schwantes, R. H., Shiraiwa, M., Zhang, X., Schilling, K. A., Ng, N. L., Canagaratna, M. R., Ziemann, P. J., Flagan, R. C., and Seinfeld, J. H.: Secondary organic aerosol yields of 12-carbon alkanes, Atmos. Chem. Phys., 14, 1423-1439, https://doi.org/10.5194/acp14-1423-2014, 2014.

Martínez-Lozano, P., Rus, J., de la Mora, G. F., Hernández, M., and de la Mora, J. F.: Secondary electrospray ionization (SESI) of ambient vapors for explosive detection at concentrations below parts per trillion, J. Am. Soc. Mass Spec., 20, 287-294, 2009.

McVay, R. C., Zhang, X., Aumont, B., Valorso, R., Camredon, M., La, Y. S., Wennberg, P. O., and Seinfeld, J. H.: SOA formation from the photooxidation of $\alpha$-pinene: systematic exploration of the simulation of chamber data, Atmos. Chem. Phys., 16, 27852802, https://doi.org/10.5194/acp-16-2785-2016, 2016.

Nah, T., McVay, R. C., Zhang, X., Boyd, C. M., Seinfeld, J. H., and $\mathrm{Ng}, \mathrm{N}$. L.: Influence of seed aerosol surface area and oxidation rate on vapor wall deposition and SOA mass yields: a case study with $\alpha$-pinene ozonolysis, Atmos. Chem. Phys., 16, 9361-9379, https://doi.org/10.5194/acp-16-9361-2016, 2016.

Nguyen, T. B., Coggon, M. M., Bates, K. H., Zhang, X., Schwantes, R. H., Schilling, K. A., Loza, C. L., Flagan, R. C., Wennberg, P. O., and Seinfeld, J. H.: Organic aerosol formation from the reactive uptake of isoprene epoxydiols (IEPOX) onto nonacidified inorganic seeds, Atmos. Chem. Phys., 14, 3497-3510, https://doi.org/10.5194/acp-14-3497-2014, 2014a.

Nguyen, T. B., Crounse, J. D., Schwantes, R. H., Teng, A. P., Bates, K. H., Zhang, X., St Clair, J. M., Brune, W. H., Tyndall, G. S., and Keutsch, F. N.: Overview of the Focused Isoprene eXperiment at the California Institute of Technology (FIXCIT): mechanistic chamber studies on the oxidation of biogenic compounds, Atmos. Chem. Phys., 14, 13531-13549, 2014b.

Nguyen, T. B., Bates, K. H., Crounse, J. D., Schwantes, R. H., Zhang, X., Kjaergaard, H. G., Surratt, J. D., Lin, P., Laskin, A., and Seinfeld, J. H.: Mechanism of the hydroxyl radical oxidation of methacryloyl peroxynitrate (MPAN) and its pathway toward secondary organic aerosol formation in the atmosphere, Phys. Chem. Chem. Phys., 17, 17914-17926, 2015.

O’Brien, J. M., Shepson, P. B., Muthuramu, K., Hao, C., Niki, H., Hastie, D. R., Taylor, R., and Roussel, P. B.: Measurements of alkyl and multifunctional organic nitrates at a rural site in Ontario, J. Geophys. Res.-Atmos., 100, 22795-22804, 1995.

Perring, A. E., Pusede, S. E., and Cohen, R. C.: An observational perspective on the atmospheric impacts of alkyl and multifunctional nitrates on ozone and secondary organic aerosol, Chem. Rev., 113, 5848-5870, 2013.

Popov, I. A., Chen, H., Kharybin, O. N., Nikolaev, E. N., and Cooks, R. G.: Detection of explosives on solid surfaces by thermal desorption and ambient ion/molecule reactions, Chem. Commun., 15, 1953-1955, 2005.

Riva, M., Budisulistiorini, S. H., Chen, Y., Zhang, Z., D’Ambro, E. L., Zhang, X., Gold, A., Turpin, B. J., Thornton, J. A., and Canagaratna, M. R.: Chemical characterization of secondary organic aerosol from oxidation of isoprene hydroxyhydroperoxides, Environ. Sci. Technol., 50, 9889-9899, 2016.

Rollins, A. W., Smith, J. D., Wilson, K. R., and Cohen, R. C.: Real time in situ detection of organic nitrates in atmospheric aerosols, Environ. Sci. Technol., 44, 5540-5545, 2010. 
Rollins, A. W., Browne, E. C., Min, K. E., Pusede, S. E., Wooldridge, P. J., Gentner, D. R., Goldstein, A. H., Liu, S., Day, D. A., and Russell, L. M.: Evidence for $\mathrm{NO}_{x}$ control over nighttime SOA formation, Science, 337, 1210-1212, 2012.

Rosen, R. S., Wood, E. C., Wooldridge, P. J., Thornton, J. A., Day, D. A., Kuster, W., Williams, E. J., Jobson, B. T., and Cohen, R. C.: Observations of total alkyl nitrates during Texas Air Quality Study 2000: Implications for $\mathrm{O}_{3}$ and alkyl nitrate photochemistry, J. Geophys. Res.-Atmos., 109, D07303, https://doi.org/10.1029/2003JD004227, 2004.

Russell, L. M., Bahadur, R., and Ziemann, P. J.: Identifying organic aerosol sources by comparing functional group composition in chamber and atmospheric particles, P. Natl. Acad. Sci. USA, 108, 3516-3521, 2011.

Schilling Fahnestock, K. A., Yee, L. D., Loza, C. L., Coggon, M. M., Schwantes, R., Zhang, X., Dalleska, N. F., and Seinfeld, J. H.: Secondary organic aerosol composition from C12 alkanes, J. Phys. Chem. A, 119, 4281-4297, 2014.

Schwantes, R. H., Teng, A. P., Nguyen, T. B., Coggon, M. M., Crounse, J. D., St. Clair, J. M., Zhang, X., Schilling, K. A., Seinfeld, J. H., and Wennberg, P. O.: Isoprene $\mathrm{NO}_{3}$ Oxidation Products from the $\mathrm{RO}_{2}+\mathrm{HO}_{2}$ Pathway, J. Phys. Chem. A, 119, 10158-10171, 2015.

Schwantes, R. H., McVay, R. C., Zhang, X., Coggon, M. M., Lignell, H., Flagan, R. C., Wennberg, P. O., and Seinfeld, J. H.: Science of the environmental chamber, Adv. Atmos. Chem., 1, 1-93, 2017a.

Schwantes, R. H., Schilling, K. A., McVay, R. C., Lignell, H., Coggon, M. M., Zhang, X., Wennberg, P. O., and Seinfeld, J. H.: Formation of highly oxygenated low-volatility products from cresol oxidation, Atmos. Chem. Phys., 17, 3453-3474, https://doi.org/10.5194/acp-17-3453-2017, 2017 b.

Shvartsburg, A. A., Liu, B., Jarrold, M. F., and Ho, K.-M.: Modeling ionic mobilities by scattering on electronic density isosurfaces: Application to silicon cluster anions, J. Chem. Phys., 112, 45174526, 2000.

Takáts, Z., Cotte-Rodriguez, I., Talaty, N., Chen, H., and Cooks, R. G.: Direct, trace level detection of explosives on ambient surfaces by desorption electrospray ionization mass spectrometry, Chem. Commun., 15, 1950-1952, 2005.

Tam, M. and Hill, H. H.: Secondary electrospray ionization-ion mobility spectrometry for explosive vapor detection, Anal. Chem., 76, 2741-2747, 2004.

Teng, A. P., Crounse, J. D., Lee, L., St. Clair, J. M., Cohen, R. C., and Wennberg, P. O.: Hydroxy nitrate production in the $\mathrm{OH}-$ initiated oxidation of alkenes, Atmos. Chem. Phys., 15, 42974316, https://doi.org/10.5194/acp-15-4297-2015, 2015.

Thomas, D. A., Coggon, M. M., Lignell, H., Schilling, K. A., Zhang, X., Schwantes, R. H., Flagan, R. C., Seinfeld, J. H., and Beauchamp, J. L.: Real-time studies of iron oxalate-mediated oxidation of glycolaldehyde as a model for photochemical aging of aqueous tropospheric aerosols, Environ. Sci. Technol., 50, 12241-12249, 2016

Thornton, J. A., Wooldridge, P. J., and Cohen, R. C.: Atmospheric $\mathrm{NO}_{2}$ : In situ laser-induced fluorescence detection at parts per trillion mixing ratios, Anal. Chem., 72, 528-539, 2000.

Wang, H., Zhang, X., and Chen, Z.: Development of DNPH/HPLC method for the measurement of carbonyl compounds in the aque- ous phase: applications to laboratory simulation and field measurement, Environ. Chem., 6, 389-397, 2009.

Wennberg, P. O., Bates, K. H., Crounse, J. D., Dodson, L. G., McVay, R. C., Mertens, L. A., Nguyen, T. B., Praske, E., Schwantes, R. H., and Smarte, M. D.: Gas-phase reactions of isoprene and its major oxidation products, Chem. Rev., 118, 3337-3390, 2018.

Wooldridge, P. J., Perring, A. E., Bertram, T. H., Flocke, F. M., Roberts, J. M., Singh, H. B., Huey, L. G., Thornton, J. A., Wolfe, G. M., Murphy, J. G., Fry, J. L., Rollins, A. W., LaFranchi, B. W., and Cohen, R. C.: Total Peroxy Nitrates ( $\Sigma$ PNs) in the atmosphere: the Thermal Dissociation-Laser Induced Fluorescence (TD-LIF) technique and comparisons to speciated PAN measurements, Atmos. Meas. Tech., 3, 593-607, https://doi.org/10.5194/amt-3-593-2010, 2010.

Xiong, F., McAvey, K. M., Pratt, K. A., Groff, C. J., Hostetler, M. A., Lipton, M. A., Starn, T. K., Seeley, J. V., Bertman, S. B., Teng, A. P., Crounse, J. D., Nguyen, T. B., Wennberg, P. O., Misztal, P. K., Goldstein, A. H., Guenther, A. B., Koss, A. R., Olson, K. F., de Gouw, J. A., Baumann, K., Edgerton, E. S., Feiner, P. A., Zhang, L., Miller, D. O., Brune, W. H., and Shepson, P. B.: Observation of isoprene hydroxynitrates in the southeastern United States and implications for the fate of $\mathrm{NO}_{x}$, Atmos. Chem. Phys., 15, 11257-11272, https://doi.org/10.5194/acp-1511257-2015, 2015.

Xu, W., Croteau, P., Williams, L., Canagaratna, M., Onasch, T., Cross, E., Zhang, X., Robinson, W., Worsnop, D., and Jayne, J.: Laboratory characterization of an aerosol chemical speciation monitor with $\mathrm{PM}_{2.5}$ measurement capability, Aerosol Sci. Tech., 51, 69-83, 2017.

Xu, W., Lambe, A., Silva, P., Hu, W., Onasch, T., Williams, L., Croteau, P., Zhang, X., Renbaum-Wolff, L., and Fortner, E.: Laboratory evaluation of species-dependent relative ionization efficiencies in the Aerodyne Aerosol Mass Spectrometer, Aerosol Sci. Tech., 52, 626-641, 2018.

Zhang, X. and Seinfeld, J. H.: A functional group oxidation model (FGOM) for SOA formation and aging, Atmos. Chem. Phys., 13, 5907-5926, https://doi.org/10.5194/acp-13-5907-2013, 2013.

Zhang, X., Cappa, C. D., Jathar, S. H., McVay, R. C., Ensberg, J. J., Kleeman, M. J., and Seinfeld, J. H.: Influence of vapor wall loss in laboratory chambers on yields of secondary organic aerosol, $\mathrm{P}$. Natl. Acad. Sci. USA, 111, 5802-5807, 2014a.

Zhang, X., Schwantes, R. H., Coggon, M. M., Loza, C. L., Schilling, K. A., Flagan, R. C., and Seinfeld, J. H.: Role of ozone in SOA formation from alkane photooxidation, Atmos. Chem. Phys., 14, 1733-1753, https://doi.org/10.5194/acp-14-1733-2014, 2014b.

Zhang, X., McVay, R. C., Huang, D. D., Dalleska, N. F., Aumont, B., Flagan, R. C., and Seinfeld, J. H.: Formation and evolution of molecular products in $\alpha$-pinene secondary organic aerosol, $\mathrm{P}$ Natl. Acad. Sci. USA, 112, 14168-14173, 2015a.

Zhang, X., Schwantes, R. H., McVay, R. C., Lignell, H., Coggon, M. M., Flagan, R. C., and Seinfeld, J. H.: Vapor wall deposition in Teflon chambers, Atmos. Chem. Phys., 15, 4197-4214, https://doi.org/10.5194/acp-15-4197-2015, 2015 b.

Zhang, X., Dalleska, N. F., Huang, D. D., Bates, K. H., Sorooshian, A., Flagan, R. C., and Seinfeld, J. H.: Time-resolved molecular characterization of organic aerosols by PILS + UPLC/ESI-QTOFMS, Atmos. Environ., 130, 180-189, 2016a.

Zhang, X., Krechmer, J. E., Groessl, M., Xu, W., Graf, S., Cubison, M., Jayne, J. T., Jimenez, J. L., Worsnop, D. R., and Cana- 
garatna, M. R.: A novel framework for molecular characterization of atmospherically relevant organic compounds based on collision cross section and mass-to-charge ratio, Atmos. Chem. Phys., 16, 12945-12959, https://doi.org/10.5194/acp-16-129452016, 2016b.

Zhang, X., Lambe, A. T., Upshur, M. A., Brooks, W. A., Gray Be1, A., Thomson, R. J., Geiger, F. M., Surratt, J. D., Zhang, Z., and Gold, A.: Highly oxygenated multifunctional compounds in $\alpha$ pinene secondary organic aerosol, Environ. Sci. Technol., 51, 5932-5940, 2017.

Zhang, X., Ortega, J., Huang, Y., Shertz, S., Tyndall, G. S., and Orlando, J. J.: A steady-state continuous flow chamber for the study of daytime and nighttime chemistry under atmospherically relevant NO levels, Atmos. Meas. Tech., 11, 2537-2551, https://doi.org/10.5194/amt-11-2537-2018, 2018.
Zhao, Y., Chen, Z., Shen, X., and Zhang, X.: Kinetics and mechanisms of heterogeneous reaction of gaseous hydrogen peroxide on mineral oxide particles, Environ. Sci. Technol., 45, 33173324, 2011.

Zhu, J. and Cole, R. B.: Formation and decompositions of chloride adduct ions, $[\mathrm{M}+\mathrm{Cl}]^{-}$, in negative ion electrospray ionization mass spectrometry, J. Am. Soc. Mass Spec., 11, 932-941, 2000. 